\title{
Gut permeability in infants with cow's milk allergy
} Svetlana Makarova ${ }^{1 *}$, Leila Namasova-Baranova', Tatiana Borovik', Galina Yatsyk', Ivan Gmoshinskiy²,
Vladimir Mazo ${ }^{2}$

From Food Allergy and Anaphylaxis Meeting 2014

Dublin, Ireland. 9-11 October 2014

Our previous study revealed that newborns had a high level of absorption of human milk $\alpha$-lactalbumin. [1] It decreased during the first month in the whole and nonallergic infants showed a 4- fold reduction of gut permeability at 25-30 days of life. But patients with early allergic symptoms have increased gut permeability in comparison to non-allergic infants. In this study we examined gut permeability in infants with food allergy.

29 infants with skin and gastrointestinal symptoms of food allergy and 15 non-atopic infants without any skin and gastrointestinal problems were under examination. Human milk $\alpha$-lactalbumin was measured in blood serum by ELISA after breast milk feeding. Index of absorption was calculated according to the amount of consumed breast milk.

This study revealed high level of gut permeability in infants with skin and gastrointestinal manifestations of food allergy during the first year of life. Index of absorption of human $\alpha$-lactalbumin in atopic patients was 4-fold higher than in control group at the age 3-6 months $(\mathrm{p}<0,01)$ and 5,5 fold higher than in control group at the age 6-12 months $(\mathrm{p}<0,01)$.

There was correlation between human $\alpha$-lactalbumin absorption index and serum IgE level. High level of gut permeability is the purpose for using hydrolysed formula or amino acids based formula in patients with Cow's milk allergy.

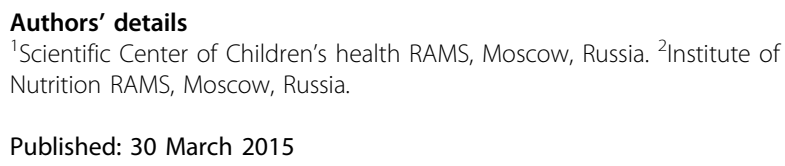

\section{Reference}

1. Makarova S, Borovik T, Skvortsova V, Yatsyk G, Gmoshinskij I, Mazo V: Increased gut permeability in newborns with food allergy. Food Allergy and Anaphylaxis Meeting 2013, poster presentation.

doi:10.1186/2045-7022-5-S3-P155

Cite this article as: Makarova et al:: Gut permeability in infants with cow's milk allergy. Clinical and Translational Allergy 2015 5(Suppl 3):P155.

Submit your next manuscript to BioMed Central and take full advantage of:

- Convenient online submission

- Thorough peer review

- No space constraints or color figure charges

- Immediate publication on acceptance

- Inclusion in PubMed, CAS, Scopus and Google Scholar

- Research which is freely available for redistribution

Submit your manuscript at www.biomedcentral.com/submit
() Biomed Central
C Biomed Central

(c) 2015 Makarova et al; licensee BioMed Central Ltd. This is an Open Access article distributed under the terms of the Creative Commons Attribution License (http://creativecommons.org/licenses/by/4.0), which permits unrestricted use, distribution, and reproduction in any medium, provided the original work is properly cited. The Creative Commons Public Domain Dedication waiver (http://creativecommons.org/publicdomain/zero/1.0/) applies to the data made available in this article, unless otherwise stated. 